\title{
ÅSE MARIE OMMUNDSEN, PER THOMAS ANDERSEN OG LIV BLIKSRUD (RED.) MODERNITET, BARNDOM, HISTORIE Festskrift til Harald Bache-Wiig
}

Oslo: Novus forlag, 2016 (335 s.)

For den som ville studere barnelitteratur i Norge var Nordisk institutt på Universitet i Oslo det opplagte stedet å henvende seg i den tiden Harald Bache-Wiig og Åsfrid Svensen ledet et eget semesteremne i barnelitteratur. De to lærerne bygget opp et engasjerende studium som kom til å få ringvirkninger for den barnelitterære norske offentligheten. Dagens forlagsredaktører har vært deres studenter, mange bibliotekarer og informasjonsarbeidere har tatt tilleggsutdanning hos dem.

Svensen og Bache-Wiig var sentrale i et norsk pionér-nettverk som bygget opp barnelitteraturstudier og -forskning forskjellige steder i Norge. Med forskningsprosjektet Etableringen av den norske barndommen var Harald Bache-Wiig sentral i arbeidet for å fremme forståelsen av hvordan barnelitteratur er preget av synet på barndom, og hvordan den litterære modernismen påvirket utviklingen av det litterære barneperspektivet. Skjønt hans egne bidrag handlet om skriftlige medier, åpnet han gjennom prosjektet for den barnelitterære medieforskningen, som er blitt svært sentral i nyere norsk barnelitteraturforskning.

Etter at Svensen og Bache-Wiig pensjonerte seg har barnelitteraturkompetansen blitt sterkt svekket på Universitetet i Oslo, men den er blitt styrket andre steder. De to er blitt pensum og deres forskningsinnsats et springbrett for nye forskere. I 2006 redigerte BacheWiig et festkrift til Svensens ære. I 2016 har Åse Marie Ommundsen, Per Thomas Andersen og Liv Bliksrud (som alle tre enten er ansatt ved, eller har bakgrunn fra Seksjon for Nordisk litteratur, Institutt for nordiske og lingvistiske studier, Universitetet i Oslo, der professor emeritus Harald Bache-Wiig har hatt sitt daglige virke helt siden 1984) redigert et festskrift til hans ære.

Et festskrift er en gave. Tradisjonen skal stamme fra 1600-tallet. Professorer og kulturpersonligheter kan forvente å bli hedret med en artikkelsamling for sin langvarige innsats, når de går av med pensjon 
eller når de fyller et høyt, rundt år. Det forventes at festskriftet gir et direkte eller indirekte portrett av den som æres ved at deres særlige innsats som fagperson fremheves.

Redigeringsprinsippet er gjerne ett av to: Redaktørene samler de viktigste artiklene som den som skal hedres har skrevet i ulike fora, gir dem ut på nytt, samlet, i en bok. Da består gaven i at vedkommendes langvarige innsats for utviklingen av fagfeltet blir ekstra synlig. Harald Bache-Wiig har vært redaktør for to festskrift som er redigert etter dette prinsippet, til henholdsvis Gudleiv Bø i 2009 og Liv Bliksrud i 2015, begge kollegaer fra hans eget institutt.

Alternativt inviterer redaktørene sentrale personer i hedersmannen eller -kvinnens fagfelt til å skrive hver sin nye artikkel til vedkommende. Det forventes at hvert bidrag speiler krysspunktet mellom artikkelforfatterens og jubilantens forskningsfelter. Slik fremstår hver enkelt artikkel i festskriftet som en faglig dialog med jubilanten. Og den samlede gaven består i å vise hvor stor betydning jubilanten har hatt som inspirator for fagutviklingen. I Norden har nettopp slike festskrifter vært sentrale publiseringsarenaer for nyere forskning på barnelitteratur. Harald Bache-Wiig benyttet dette prinsippet i festskriftet til Åsfrid Svensen; På terskelen (2006). Det bildet som indirekte gis av henne er at hun har vært en drivkraft for norsk forskning om barne- og ungdomslitteratur.

Også festskriftet til Harald Bache-Wiig er redigert som en faglig samtale der jubilanten fremstår gjennom de emner som antologien presenterer. Redaktørene har samlet 13 kollegaer fra instituttet og fem fra det nordiske barnelitteraturforskningsmiljøet til en diskusjon om hans betydning for (ifølge tittelen) synet på modernitet, barndom og historie.

Det er mange spenstige artikler om barnelitteratur her. Åsfrid Svensen argumenterer for at ungdomsromansjangeren er i endring, Marianne Egeland henter opp Stompa til allmenn gjensynsglede og Torill Steinfeld gir interessante analyser av glemte norske robinsonader, for bare å nevne noen av Bache-Wiigs lokale kollegaer, som benytter anledningen til å diskutere barnelitteratur med ham. De drøfter stemme, identitetskonstruksjoner og virkelighetsforankring, og kombinerer adaptasjonsteori, oversettelsesfokus og historisk kontekst.

Den morsomste artikkelen er signert Boel Westin. (Tenk om hun kunne samle de ulike artiklene hun har gitt ut gjennom årene om barnelitteraturens dyr og andre ikke-menneskelige hovedpersoner!) Denne gangen har hun bearbeidet sin kaninartikkel fra 2014. Utgangspunktet er noen av de utrolig mange kulturelle kaninene fra barnelitteratur, film, musikk og billedkunst. Westin setter opp 
en kaninkanon og argumenterer for at den fungerer som en kulturell projeksjonsflate. Derav nyordet kaninym: en fremstilling som gjennom sin transformative karakter kan sette spørsmålstegn ved forestillinger om kultur, kunst eller dyr (68).

Maria Nikolajevas artikkel fremstår tydeligst av alle som en gest til en kjær kollega. Bache-Wiig har tidligere skrevet om Zinken Hopp's Trollkrittet (1948) og Lewis Carroll's Alice in Wonderland (1865), som Nikolajeva gjør nå. Hun diskuterer barndomssynet i de to verkene og går derved i dialog med hans forskning på hvordan barnelitteraturen speiler synet på barndom.

Nina Christensen går inn i det medieforskningsfeltet som Harald Bache-Wiig åpnet for med Etableringen av den norske barndommen. Selv har Christensen tidligere skrevet om Halfdan Rasmussens oversettelse av Thorbjørn Egner. Nå tar hun for seg én av deres felles karakterer, tante Sofie. Gjennom innsiktsfulle analyser av stemme, musikk og bilde, i radio, bok og drama benytter Christensen tante Sofie til å argumentere for at barnelitterære fortellinger like gjerne skal lyttes til som leses.

I forordet, som er et sjangerkarakteristisk portrett av 70-års jubilanten, presenterer Åse Marie Ommundsen Bache-Wiigs pionérinnsats for å bygge opp en norsk barne- og ungdomslitteraturforskning i tett kontakt med et nordisk og internasjonalt fagmiljø. Bredden i hans forskningsinnsats, at han arbeidet med veldig mye annet også, blir nevnt, som forklaring på festskriftets komposisjon. Men i lys av at mange av festskriftets bidrag ikke handler om barnelitteratur, kunne denne delen av Bache-Wiigs virke fått mer oppmerksomhet. Den etterfølgende, usignerte og separate presentasjonen av artiklene motiverer dem heller ikke i forhold til Bache-Wiigs egne publikasjoner.

Derfor er det Anne Kristin Landes bibliografi over Bache-Wiigs forskning som fungerer som en nøkkel til bidragene. For eksempel blir Jorunn Hareides artikkel om Magdalene Thoresen og Thorstein Norheims om Dag Solstad mer relevante for leseren som oppdager at Bache-Wiig både har skrevet om Arne Garborgs Bondestudentar (1883), som Thoresens tekst feilaktig forbindes med, ifølge Hareide, og om Solstad selv. Hadde artikkelforfatterne vist til Bache-Wiigs artikler ville leseren blitt enda bedre informert om hvordan de diskuterer med ham.

Landes bibliografi legitimerer festskriftets mangfold ved å synliggjøre Bache-Wiigs faglige bredde og forskningsinnsats. Materialet han har arbeidet med er utkommet fra 1700-tallet til i dag. Det har vært henvendt til barn, ungdom og voksne og er hentet fra lesebøker og brev, aviser, noveller og romaner. Dessuten har han redigert an- 
dre forskeres artikler om radio-mediet. Bibliografien avslører dessuten at Bache-Wiig har gitt ut hele to monografier om Jonas Lie. Det undrer meg derfor at ingen av festskriftets artikler diskuterer Lie med Bache-Wiig. Han har skrevet om lek i forbindelse med barnelitteratur, det er det heller ingen som skriver om her.

Redaktørene gjør intet forsøk på å pensle ut noen tydelige diskusjonstråder mellom artiklene. Hovedtittelen Modernitet, barndom, historie favner vidt, men begrepene blir ikke nærmere presisert. Del-overskriftene "Barnelitteratur", "Barndom og barn som motiv i litteratur", "Samtidslitteratur", og "Eldre litteratur" virker ryddige, men hvorfor er Mia Österlunds artikkel om en av Tove Janssons romaner for voksne plassert som barnelitteraturforskning? Og hvorfor er artiklene om Jørgen Moe plassert under ulike seksjoner?

En alternativ ordning kunne vært å synliggjøre de ulike problemstillingene som blir behandlet i artiklene. Under en overskrift som Barnelitterære dyr kunne Anne Karlskov Skyggebjergs artikkel om isbjørner i barnelitterær sakprosa og Westins om kaninens kulturelle funksjon blitt til en dialog om den betydning som tillegges dyr. Under en overskrift som kjønn og seksualitet kunne Mia Österlund, Liv Bliksrud og Gudleiv Bøs artikler om henholdsvis Tove Jansson, Bergljot Hobæk Haff, H.C. Andersen og Asbjørnsen og Moe få anledning til å 'snakke sammen'. Ved å samle Per Thomas Andersens og Irene Engelstad artikler om henholdsvis Søren Kierkegaard og Lars Ramslie under overskriften Etikk og estetikk, ville deres innspill om psykoanalytisk teori og filosofiske og religiøse problemstillinger kunne ha bidratt til å fremme en mer innsiktsfull litteraturdiskusjon når talen er om litterær etikk, som den så ofte er nå, i hvert fall i den norske offentligheten.

At det ikke er innført en felles måte å referere på sender et signal om at redaksjonen har hatt det for travelt. Det er flere unøyaktigheter her. Verk-titler oppføres med ulike årstall innad i samme artikkel. Henvisninger i artiklene er uteglemt fra litteraturlistene. Det er til og med trykkfeil i så korte tekster som presentasjonen av bidragsyterne.

Festskriftets styrke er mange interessante artikler. Jubilanten skrives frem som en svært mangfoldig forsker som ikke lar seg plassere i én bås. Dersom forordet og presentasjonen av artiklene ble omskrevet til én tekst som la an på å presentere Bache-Wiig, hans forskningsinteresser og knyttet festskriftartiklene til dem, ville hver enkelt artikkel blitt mer synlig og deres relevans som speil for hovedpersonens betydning for fagutviklingen mer innlysende.

Kristin Ørjasæter

Dr. art i litteraturvitenskap, Direktør for Norsk barnebokinstitutt 